\title{
MOVEMENT GAMES IN VARIOUS KINDS OF SPORT (EXPERIENCES OF COACHES STUDYING AT LASE)
}

\author{
Irena Dravniece \\ Latvian Academy of Sport Education, Riga, Latvia
}

\begin{abstract}
Background. Practice game contributes to the development of coordinated motor skills needed for later game playing or sport. When coaches know and use movement games corresponding to the specific sport to increase athlete's interest and pleasure about sport and sport pedagogue's knowledge about the scientifically based movement games, they promote the acquisition of skills at higher levels. Research aim was to ascertain the knowledge of coaches about movement games in sport classes, in order to research the use of movement games in the training process in different sports and to investigate how games are applied in the training process in Latvia.

Methods. The methods of research were analysis of the literature corresponding to the research problem, questionnaire and discussions with coaches, statistical methods. The study was conducted in $2010-2012$ in Riga, LASE. There were 96 research participants - simultaneously practicing coaches and the extramural students of the LASE.

Results. In the study process we investigated and evaluated the knowledge of coaches and their opinions regarding movement games: development of physical abilities, improvement of the sport technique, development of social skills, and the experience in using movement games in training classes. Responses to the first three questions were compared with those obtained in the questionnaire survey in 1994.

Conclusions. The questionnaire survey showed that coaches were willing to apply movement games. Some of them also were sceptic about using movement games in sport activities; $94 \%$ admitted that games facilitated physical abilities, $87.5 \%$ agreed that games aided in the development of sport techniques, and $85 \%$ of respondents were confident that games contributed to building up social skills. In the questionnaire of 1994, the number of those who considered that games were essential in training was similar to those in the questionnaire survey of 2012 respectively 80 and $84 \%$. In total, movement games were applied by $61 \%$ of different sports coaches (1994) in comparison with $79 \%$ today. Changes in indices were statistically significant $(p<.05)$. Even $18 \%$ more respondents gave preference to games in the questionnaire survey of 2012 than in the questionnaire survey of 1994.
\end{abstract}

Keywords: coaches, questionnaire survey, knowledge, movement games.

\section{INTRODUCTION}

$\mathrm{T}$ he purpose of the research was to ascertain the knowledge of coaches about movement games in sport classes in order to research the use of movement games in the training process in different sports. Research idea was to investigate how games were applied in the training process in Latvia based on the coaches' knowledge and practical experience in the use of movement games. Movement games are games with motion and possibly with competitive activities, with previously developed and known content, rules, goal, organisation and pleasure (Dravniece, 2013; Laizane, 1981). This definition is similar to the definitions_given by other authors (Dauer \& Pangrazi, 1989; H. Haag \& G. Haag, 2003). In every sport children should be interested to enjoy movement in the first place. The best way to do it is to use movement games. Interesting and 
varied physical activities establish positive attitude towards sport that ensures willingness to continue excercising. Games permit children to practise their competencies and acquired skills in a relaxed, pleasurable way. Play involves the repetition of behaviour when new skills are learned or when physical or mental mastery and coordination of skills are required for games in sports. Practise play contributes to the development of coordinated motor skills needed for later game playing (Santrock, 2001). As an integral part of the physical education program, games need to be scrutinized carefully and evaluated in terms of what they offer to children. Children and teachers can create and modify games and adjust them to various needs by changing the rules and combining games with each other (Dauer \& Pangrazi, 1989; Dravniece, 2013; H. Haag \& G. Haag, 2003). Coaches should view games as a valuable contribution to the child's overall development. While playing children can apply newly learned skills in a meaningful way. Many games help develop large muscle groups and enhance the child's ability to run, dodge, start and stop under control while sharing space with others. Cognitive development also enhances as children learn, understand and follow rules. By applying strategy in games, children learn the importance of alertness and the mental aspect of participation (Dauer \& Pangrazi, 1989). A game in sport is a method and means, as well as the way of movement activity organization; a game is a necessary part of movement activity, especially with pupils and adolescents. Games include several important tasks: developmental, educational, upbringing and health promoting (Dauer \& Pangrazi, 1989; Dravniece, 1999; Dzintere \& Stangaine, 2007; Jansone \& Fernāte, 2009; Santrock, 2001). When coaches know and use movement games corresponding to a specific sport to increase athlete's interest and pleasure about sport and sport pedagogue's knowledge about the scientifically based movement games, they promote the acquisition of skills for the right kind of sport at a higher level.

\section{METHODS}

The subject of the research was the investigation of coaches' knowledge and experience in the use of movement games in the training process in various kinds of sport and comparing these data with those obtained in the questionnaire survey of 1994 . We used theoretical, empirical and statistical research methods in the study. The methods of research were analysis of the literature corresponding to the research problem, questionnaire survey and discussions with coaches of different kinds of sport. In the statistical processing of the data we used $t$-test and the Spearman's rank correlation coefficient. The study was conducted in 2010 2012 in Riga, LASE.

Research participants. For the purposes of the survey 96 persons $(n=96)$ were surveyd, namely, practicing coaches which simultaneously were the extramural students of the LASE $(n=56)$ or the students of the first cycle higher professional education programme "Educational and sport teaching specialist" $(n=40)$. They were coaches who were working in sport but still without sports education. In order to increase the objectivity, the questionnaire survey was conducted before the beginning of the course of games. The surveyed coaches represented 37 kinds of sport, which were combined in 14 groups of related sports, i.e. 15 represented track-and-field, 15 - wrestling sports, boxing, power-lifting, ten - gymnastics, fitness, aerobics, yoga, nine - football, eight - basketball, seven - volleyball, five - ice hockey, five - floorball, four - swimming, two - rowing, two - skiing, two - tennis, two - handball, two - orienteering, and one in cycling, riding, shooting, climbing, parachuting, chess, lacrosse and motorsport. When the individual kind of sport was represented only by one respondent, the answers were considered only as informative and could not be generalized to the common situation in a particular kind of sport. The survey involved men and women aged 19 to 56 years. There was a tendency that in older age groups there were more women than men. Among the students over 30 years of age, $55 \%$ were women and $45 \%$ were men. There were 46 respondents from Riga and 50 respondents from other Latvian cities; $71 \%$ of respondents were in the age group under 25 years, $20 \%$ were $26-39$ years old, $9 \%$ over 40 years old. We compared the responses to the first three questions with those obtained in the questionnaire survey in 1994. In 1994 the answers were given by 129 respondents $(n=129)$ representing different sports, mostly basketball players, athletes, rowers, wrestlers, gymnasts, swimmers and skiers.

Instruments. The questionnaire was anonymous, in general it was a mixed type of questionnaire - questions were both close and open ended. The hard copy of the questionnaire for coaches included 11 questions. The first 6 questions were closed and responses were used in aggregated form 
only. Responses were limited to the stated alternatives; one of the alternatives was simply "yes" or "no". The questionnaires were prepared well in advance, they were structured and testable, and they had definite and concrete questions. The questions were the same in 1994 and 2012. The questionnaire comprised questions in total relating to the use of games in the training process, as well as about educational, developmental and upbringing functions of games. In this article we analysed replies given in six questions relating to the application of movement games in different sports. These questions were the following:

1. Were movement games included in your training classes (when you were training)?

2. Do you include movement games in your training classes?

3. In your opinion, are movement games essential in the training process?

4. Is it possible to develop physical abilities using movement games?

5. Is it possible to improve the sport technique using movement games?

6. Is it possible to develop social skills using movement games?

\section{RESULTS}

We investigated and evaluated the knowledge of coaches and their opinions regarding the movement games and the experience in the use of movement games in the training classes in different sports. Responses to the first three questions were compared with those obtained in the questionnaire survey in 1994. These replies were summarized in Tables 2, 3, 4.

The summary of responses to questions one, two and three in 2012 is given in Table 1.

Responding to the first question: "Were movement games included (when you were training)?" the majority of respondents $(65.6 \%)$ gave an affirmative answer, while $34.4 \%$ said no. Movement games in the course of training mostly were applied by basketball (87.5\%), volleyball $(85.7 \%)$, ice hockey $(80 \%)$ coaches, as well as in skiing, handball and in orienteering. Surprisingly, only $55.6 \%$ of football, $73.3 \%$ of track-and-field, $66.7 \%$ of wrestling, $60 \%$ of floor-ball coaches applied movement games in their coaching practice. There were several sports such as yoga, parachuting, possibly some other sports, where

Table 1. Responses to questions 1-3 (The questionnaire survey of 2012)

\begin{tabular}{|c|c|c|c|c|c|c|c|c|c|c|c|c|c|}
\hline & \multirow{3}{*}{ 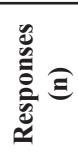 } & \multicolumn{4}{|c|}{ Games were included } & \multicolumn{4}{|c|}{ Games are included } & \multicolumn{4}{|c|}{ Games are essential } \\
\hline & & \multicolumn{2}{|c|}{ Yes } & \multicolumn{2}{|c|}{ No } & \multicolumn{2}{|c|}{ Yes } & \multicolumn{2}{|c|}{ No } & \multicolumn{2}{|c|}{ Yes } & \multicolumn{2}{|c|}{ No } \\
\hline & & Abs. No & $\%$ & Abs. No & $\%$ & Abs. No & $\%$ & Abs. No & $\%$ & Abs. No & $\%$ & Abs. No & $\%$ \\
\hline Track-and-field & 15 & 11 & 73.3 & 4 & 26.67 & 11 & 73 & 4 & 27 & 12 & 80 & 3 & 20 \\
\hline Wrestling & 15 & 10 & 66.7 & 5 & 33.33 & 11 & 73 & 4 & 27 & 12 & 80 & 3 & 20 \\
\hline Gymnastics & 10 & 7 & 70.0 & 3 & 30.0 & 8 & 80 & 2 & 20 & 8 & 80 & 2 & 20 \\
\hline Football & 9 & 5 & 55.6 & 4 & 44.44 & 7 & 78 & 2 & 22 & 7 & 78 & 2 & 22 \\
\hline Basketball & 8 & 7 & 87.5 & 1 & 12.5 & 8 & 100 & - & 100 & 8 & 100 & - & - \\
\hline Volleyball & 7 & 6 & 85.7 & 1 & 14.29 & 6 & 86 & 1 & 14 & 7 & 100 & - & - \\
\hline Ice hockey & 5 & 4 & 80.0 & 1 & 20.0 & 5 & 100 & - & 100 & 5 & 100 & - & - \\
\hline Floor-ball & 5 & 3 & 60.0 & 2 & 40.0 & 3 & 60 & 2 & 40 & 3 & 60 & 2 & 40 \\
\hline Swimming & 4 & 2 & 50.0 & 2 & 50.0 & 3 & 75 & 1 & 25 & 4 & 100 & - & - \\
\hline Rowing & 2 & 1 & 50.0 & 1 & 50.0 & 2 & 100 & - & 0 & 1 & 50 & 1 & 50 \\
\hline Skiing & 2 & 2 & 100.0 & - & - & 2 & 100 & - & 0 & 2 & 100 & - & - \\
\hline Tennis & 2 & 1 & 50.0 & 1 & 50.0 & 2 & 100 & - & 0 & 2 & 100 & - & - \\
\hline Handball & 2 & 2 & 100.0 & - & - & 2 & 100 & - & 0 & 2 & 100 & - & - \\
\hline Orienteering & 2 & 2 & 100.0 & - & - & 2 & 100 & - & 0 & 2 & 100 & - & - \\
\hline Cycling & 1 & - & & 1 & 100.0 & - & & 1 & 100.0 & 1 & 100.0 & - & \\
\hline Riding & 1 & - & & 1 & 100.0 & - & & 1 & 100.0 & - & & 1 & 100.0 \\
\hline Shooting & 1 & - & & 1 & 100.0 & 1 & 100,0 & - & & 1 & 100.0 & - & \\
\hline Climbing & 1 & - & & 1 & 100.0 & 1 & 100,0 & - & & - & & 1 & 100.0 \\
\hline Parachuting & 1 & - & & 1 & 100.0 & - & & 1 & 100.0 & 1 & 100.0 & - & \\
\hline Chess & 1 & - & & 1 & 100.0 & - & & 1 & 100.0 & 1 & 100.0 & - & \\
\hline Lacrosse & 1 & - & & 1 & 100.0 & 1 & 100,0 & - & & 1 & 100.0 & - & \\
\hline Motorsport & 1 & - & & 1 & 100.0 & 1 & 100,0 & - & & 1 & 100.0 & - & \\
\hline Total: & 96 & 63 & 65.6 & 33 & 34.4 & 76 & 79,2 & 20 & 20.8 & 81 & 84.4 & 15 & 15.6 \\
\hline
\end{tabular}


Table 2. Responses to the question "Were movement games included in your training classes?" in 1994 and 2012

\begin{tabular}{|c|c|c|c|c|c|c|c|c|c|c|}
\hline \multirow{3}{*}{ Kind of sport } & \multicolumn{5}{|c|}{ Responses in 1994} & \multicolumn{5}{|c|}{ Responses in 2012} \\
\hline & \multirow{2}{*}{ 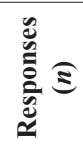 } & \multicolumn{2}{|c|}{ Yes } & \multicolumn{2}{|c|}{ No } & \multirow{2}{*}{ 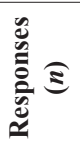 } & \multicolumn{2}{|c|}{ Yes } & \multicolumn{2}{|c|}{ No } \\
\hline & & Abs. No & $\%$ & Abs. No & $\%$ & & Abs. No & $\%$ & Abs. No & $\%$ \\
\hline Track-and-field & 14 & 11 & 78.6 & 3 & 21.4 & 15 & 11 & 73.3 & 4 & 26.7 \\
\hline Wrestling & 12 & 11 & 91.7 & 1 & 8.3 & 15 & 10 & 66.7 & 5 & 33.3 \\
\hline Gymnastics & 10 & 5 & 50.0 & 5 & 50.0 & 10 & 7 & 70.0 & 3 & 30.0 \\
\hline Football & 7 & 4 & 57.1 & 3 & 42.9 & 9 & 5 & 55.6 & 4 & 44.4 \\
\hline Basketball & 32 & 19 & 59.4 & 13 & 40.6 & 8 & 7 & 87.5 & 1 & 12.5 \\
\hline Volleyball & 5 & 2 & 40.0 & 3 & 60.0 & 7 & 6 & 85.7 & 1 & 14.3 \\
\hline Ice hockey & 2 & 2 & 100.0 & - & - & 5 & 4 & 80.0 & 1 & 20.0 \\
\hline Floor-ball & - & - & - & - & - & 5 & 3 & 60.0 & 2 & 40.0 \\
\hline Swimming & 10 & 7 & 70.0 & 3 & 30.0 & 4 & 2 & 50.0 & 2 & 50.0 \\
\hline Rowing & 12 & 4 & 33.3 & 8 & 66.7 & 2 & 1 & 50.0 & 1 & 50.0 \\
\hline Skiing & 8 & 4 & 50.0 & 4 & 50.0 & 2 & 2 & 100.0 & - & - \\
\hline Tennis & - & & & & & 2 & 1 & 50.0 & 1 & 50.0 \\
\hline Handball & 4 & 3 & 75.0 & 1 & 25.0 & 2 & 2 & 100.0 & - & - \\
\hline Orienteering & 7 & 4 & 57.1 & 3 & 42.9 & 2 & 2 & 100.0 & - & - \\
\hline Cycling & 3 & 2 & 66.7 & 1 & 33.3 & 1 & - & - & 1 & 100.0 \\
\hline Riding & - & - & - & - & - & 1 & - & - & 1 & 100.0 \\
\hline Shooting & 3 & 1 & 33.3 & 2 & 66.7 & 1 & - & - & 1 & 100.0 \\
\hline Climbing & - & - & - & - & - & 1 & - & - & 1 & 100.0 \\
\hline Parachuting & - & - & - & - & - & 1 & - & - & 1 & 100.0 \\
\hline Chess & - & - & - & - & - & 1 & - & - & 1 & 100.0 \\
\hline Lacrosse & - & - & - & - & - & 1 & - & - & 1 & 100.0 \\
\hline Motorsport & - & - & - & - & - & 1 & - & - & 1 & 100.0 \\
\hline & 129 & 79 & 61.2 & 50 & 38.8 & 96 & 63 & 65.6 & 33 & 52.4 \\
\hline
\end{tabular}

movement games due to specific reasons or age limitations of athletes were not essential, indeed. Several coaches admitted that they used movement games in training children when they started their sport activities - in the preparatory stage of the training process.

In questionnaire of 1994, some kinds of sport such as tennis, floor-ball, climbing, parachuting, riding and motorsport were not included. During the last few years, lacrosse, street gymnastics, yoga, fitness became increasingly popular.

In questionnaire survey of 1994 it was found that games were included in the training activities by $61 \%$ of respondents in comparison to $66 \%$ today, an affirmative answer was given by 79 and 63 respondents representing different sports, mostly hockey players, wrestlers, athletes and handball players (Table 2, Figure 1). There are no statistically significant differences between positions of respondents $(a=.05)$. The differences were evaluated by $t$-test.

Responses to the second question "Do you include movement games in your training classes?" the answers of coaches were more positive than to the first question. An affirmative answer was given by $79 \%$ while $21 \%$ of respondents said no. Today games in the course of training are applied by all coaches $(100 \%)$ in basketball, hockey, rowing, skiing, tennis, handball, and orienteering, the majority of volleyball (86\%), gymnastics $(80 \%)$, football (78\%) and swimming (75\%) coaches. Even those who were not trained by applying games, as coaches included these games in their work. Like in answers to the first question, games were not applied by yoga, parachuting and riding coaches.

18 years ago movement games were mostly used by volleyball, handball, wrestling, football, rowing and swimming (100\%) and basketball (93\%) coaches. In total, then movement games were applied by $61 \%$ of different sports coaches in comparison with $79 \%$ today (Table 3, Figure 1). Changes in indices are statistically significant $(p<.05) .18 \%$ more respondents gave preference to games in the questionnaire survey of 2012 than in the questionnaire survey of 1994. 
Table 3. Responses to question 2 "Do you include movement games in your training classes?" in 1994 and 2012

\begin{tabular}{|c|c|c|c|c|c|c|c|c|c|c|}
\hline \multirow{3}{*}{ Kind of sport } & \multicolumn{5}{|c|}{ Responses in 1994} & \multicolumn{5}{|c|}{ Responses in 2012} \\
\hline & \multirow{2}{*}{ 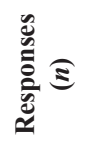 } & \multicolumn{2}{|c|}{ Yes } & \multicolumn{2}{|c|}{ No } & \multirow{2}{*}{ 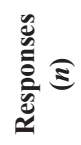 } & \multicolumn{2}{|c|}{ Yes } & \multicolumn{2}{|c|}{ No } \\
\hline & & Abs. No & $\%$ & Abs. No & $\%$ & & Abs. No & $\%$ & Abs. No & $\%$ \\
\hline Track-and-field & 14 & 13 & 92.9 & 1 & 7.1 & 15 & 11 & 73.3 & 4 & 26.7 \\
\hline Wrestling & 12 & 11 & 91.7 & 1 & 8.3 & 15 & 11 & 73.3 & 4 & 26.7 \\
\hline Gymnastics & 10 & 4 & 40.0 & 6 & 60.0 & 10 & 8 & 80.0 & 2 & 20.0 \\
\hline Football & 7 & 6 & 85.7 & 1 & 14.3 & 9 & 7 & 77.8 & 2 & 22.2 \\
\hline Basketball & 32 & 27 & 84.4 & 5 & 15.6 & 8 & 8 & 100.0 & - & - \\
\hline Volleyball & 5 & 3 & 60.0 & 2 & 40.0 & 7 & 6 & 85.7 & 1 & 14.3 \\
\hline Ice hockey & 2 & 2 & 100.0 & - & - & 5 & 5 & 100.0 & - & 100.0 \\
\hline Floor-ball & - & & & & & 5 & 3 & 60.0 & 2 & 40.0 \\
\hline Swimming & 10 & 8 & 80.0 & 2 & 20.0 & 4 & 3 & 75.0 & 1 & 25.0 \\
\hline Rowing & 12 & 8 & 66.7 & 4 & 33.3 & 2 & 2 & 100.0 & - & - \\
\hline Skiing & 8 & 8 & 100.0 & - & - & 2 & 2 & 100.0 & - & - \\
\hline Tennis & - & & & & & - & 2 & 100.0 & - & - \\
\hline Handball & 4 & 4 & 100.0 & - & - & 2 & 2 & 100.0 & - & - \\
\hline Orienteering & 7 & 5 & 71.4 & 2 & 28.6 & 2 & 2 & 100.0 & - & - \\
\hline Cycling & 3 & 3 & 100.0 & - & - & 1 & - & - & 1 & 100.0 \\
\hline Riding & - & - & - & - & - & 1 & - & - & 1 & 100.0 \\
\hline Shooting & 3 & 1 & 33.3 & 2 & 66.7 & 1 & 1 & 100.0 & - & - \\
\hline Climbing & - & - & - & - & - & 1 & 1 & 100.0 & - & - \\
\hline Parachuting & - & - & - & - & - & 1 & - & - & 1 & 100.0 \\
\hline Chess & - & - & - & - & - & 1 & - & - & 1 & 100.0 \\
\hline Lacrosse & - & - & - & - & - & 1 & 1 & 100.0 & - & - \\
\hline \multirow[t]{2}{*}{ Motorsport } & - & - & - & - & - & 1 & 1 & 100.0 & - & - \\
\hline & 129 & 79 & 61.2 & 50 & 38.8 & 96 & 76 & 79.2 & 20 & 20.8 \\
\hline
\end{tabular}

Responses to the third question "In your opinion, are movement games essential in the training process?" were quite unambiguous movement games are an essential part of the training process. This statement was supported by $84 \%$ of coaches, but $16 \%$ did not agree. All basketball, volleyball, hockey, swimming, skiing, tennis, handball, orienteering coaches agreed that movement games were essential, especially in the work with children. Some track-and-field, wrestling, floor-ball, rowing coaches claimed that games should be used in the preliminary training stages. Good tendency is that even those coaches (in cycling, parachuting, and chess) who did not use games in their training work admitted that games were an important part of the training process.

Like 18 years ago, there was a positive tendency - although only $79 \%$ of coaches applied movement games in their practical work, the number of coaches who wanted to implement games in their work was growing (84\%) (Table 4, Figure). There are no statistically significant differences between positions of respondents $(a=.05)$. The differences were evaluated by $t$-test.

Summary of responses to questions 1-3 in 1994 in comparison with 2012 is given in Figure. The picture shows that the role of games increased, especially in responses to question 2 "Do you include movement games in your training classes?" where $18 \%$ more respondents gave preference to games in the questionnaire survey of 2012 than in the questionnaire survey of 1994.

The summary of responses to questions four, five and six (in 2012) is given in Table 5.

Answering question 4 "Is it possible to develop physical abilities with movement games?" $94 \%$ of respondents gave an affirmative answer, confirming that movement games help develop physical abilities and only $6 \%$ of respondents thought otherwise. An affirmative answer was given by 
Table 4. Responses to question 3 "In your opinion, are movement games essential in the training process?" in 1994 and 2012

\begin{tabular}{|c|c|c|c|c|c|c|c|c|c|c|}
\hline \multirow{3}{*}{$\begin{array}{c}\text { Kind of } \\
\text { sport }\end{array}$} & \multicolumn{5}{|c|}{ Responses in 994} & \multicolumn{5}{|c|}{ Responses in 2012} \\
\hline & \multirow{2}{*}{ 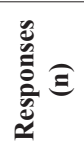 } & \multicolumn{2}{|c|}{ Yes } & \multicolumn{2}{|c|}{ No } & \multirow{2}{*}{ 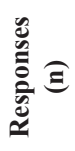 } & \multicolumn{2}{|c|}{ Yes } & \multicolumn{2}{|c|}{ No } \\
\hline & & Abs. No & $\%$ & Abs. No & $\%$ & & Abs. No & $\%$ & Abs. No & $\%$ \\
\hline Track-and-field & 14 & 13 & 92.9 & 1 & 7.1 & 15 & 12 & 80.0 & 3 & 20.0 \\
\hline Wrestling & 12 & 11 & 91.7 & 1 & 8.3 & 15 & 12 & 80.0 & 3 & 20.0 \\
\hline Gymnastics & 10 & 4 & 40.0 & - & - & 10 & 8 & 80.0 & 2 & 20.0 \\
\hline Football & 7 & 6 & 85.7 & 1 & 14.3 & 9 & 7 & 77.8 & 2 & 22.2 \\
\hline Basketball & 32 & 27 & 84.4 & 5 & 15.6 & 8 & 8 & 100.0 & - & - \\
\hline Volleyball & 5 & 3 & 60.0 & 2 & 40.0 & 7 & 7 & 100.0 & - & - \\
\hline Ice hockey & 2 & 2 & 100.0 & - & - & 5 & 5 & 100.0 & - & - \\
\hline Floor-ball & - & & & & & 5 & 3 & 60.0 & 2 & 40.0 \\
\hline Swimming & 10 & 8 & 80.0 & 2 & 20.0 & 4 & 4 & 100.0 & - & - \\
\hline Rowing & 12 & 8 & 80.0 & 2 & 20.0 & 2 & 1 & 50.0 & 1 & 50.0 \\
\hline Skiing & 8 & 8 & 100.0 & - & - & 2 & 2 & 100.0 & - & - \\
\hline Tennis & - & & & & & 2 & 2 & 100.0 & - & - \\
\hline Handball & 4 & 4 & 100.0 & - & - & 2 & 2 & 100.0 & - & - \\
\hline Orienteering & 7 & 5 & 71.4 & 2 & 28.6 & 2 & 2 & 100.0 & - & - \\
\hline Cycling & 3 & 3 & 100.0 & - & - & 1 & 1 & 100.0 & - & - \\
\hline Riding & - & & & & & 1 & - & & 1 & \\
\hline Shooting & 3 & 1 & 33.3 & 2 & 66.7 & 1 & 1 & 100.0 & - & \\
\hline Climbing & - & & & & & 1 & - & & 1 & 100.0 \\
\hline Parachuting & - & & & & & 1 & 1 & 100.0 & - & \\
\hline Chess & - & & & & & 1 & 1 & 100.0 & - & \\
\hline Lacrosse & - & & & & & 1 & 1 & 100.0 & - & \\
\hline Motorsport & - & & & & & 1 & 1 & 100.0 & - & \\
\hline & 129 & 103 & 79.8 & 26 & 20.2 & 96 & 81 & 84.4 & 15 & 15.6 \\
\hline
\end{tabular}

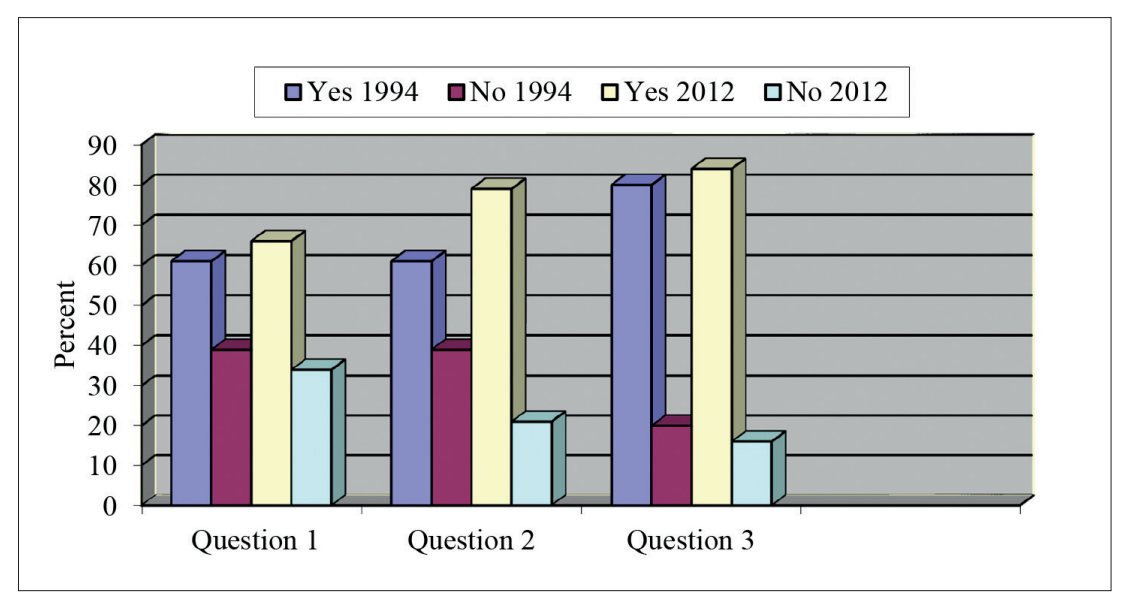

Figure 1. Responses to questions $\mathbf{1}-\mathbf{3}$ in 1994 and 2012 (Summary of Tables 2, $3,4)$

all gymnastics, football, basketball, volleyball, floor-ball, swimming, rowing, skiing, tennis and orienteering coaches and $40 \%$ of hockey coaches.

Answering question 5 "Is it possible to improve the technique with movement games?" $87.5 \%$ of respondents said "yes" and $12.5 \%$ said "no". The majority of respondents agreed that movement games facilitated the development of sport technique, while $33 \%$ of football, $20 \%$ of trackand-field, wrestling and hockey coaches, 14\% of volleyball, and $10 \%$ of gymnastics coaches thought otherwise.

Answering question 6 "Is it possible to develop social skills with movement games?" $85 \%$ of 
Table 5. Responses to questions 4-6 (in 2012)

\begin{tabular}{|c|c|c|c|c|c|c|c|c|c|c|c|c|c|}
\hline & \multirow{3}{*}{ 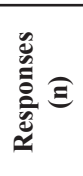 } & \multicolumn{4}{|c|}{ Develops physical abilities } & \multicolumn{4}{|c|}{ Improves the technique } & \multicolumn{4}{|c|}{ Develops social skills } \\
\hline & & \multicolumn{2}{|c|}{ Yes } & \multicolumn{2}{|c|}{ No } & \multicolumn{2}{|c|}{ Yes } & \multicolumn{2}{|c|}{ No } & \multicolumn{2}{|c|}{ Yes } & \multicolumn{2}{|c|}{ No } \\
\hline & & $\begin{array}{c}\text { Abs. } \\
\text { No. }\end{array}$ & $\%$ & $\begin{array}{l}\text { Abs } \\
\text { No. }\end{array}$ & $\%$ & $\begin{array}{c}\text { Abs. } \\
\text { No. }\end{array}$ & $\%$ & $\begin{array}{c}\text { Abs. } \\
\text { No. }\end{array}$ & $\%$ & $\begin{array}{c}\text { Abs. } \\
\text { No. }\end{array}$ & $\%$ & $\begin{array}{c}\text { Abs. } \\
\text { No. }\end{array}$ & $\%$ \\
\hline Track-and-field & 15 & 13 & 86.7 & 2 & 13.3 & 12 & 80.0 & 3 & 20.0 & 12 & 80.0 & 3 & 20.0 \\
\hline Wrestling & 15 & 14 & 93.3 & 1 & 6.7 & 12 & 80.0 & 3 & 20.0 & 13 & 86.7 & 2 & 13.3 \\
\hline Gymnastics & 10 & 10 & 100.0 & - & - & 9 & 90.0 & 1 & 10.0 & 9 & 90.0 & 1 & 10.0 \\
\hline Football & 9 & 9 & 100.0 & - & - & 6 & 66.7 & 3 & 33.3 & 7 & 77.8 & 2 & 22.2 \\
\hline Basketball & 8 & 8 & 100.0 & - & - & 8 & 100.0 & - & 0 & 8 & 100.0 & - & - \\
\hline Volleyball & 7 & 7 & 100.0 & - & - & 6 & 85.7 & 1 & 14.3 & 5 & 71.4 & 2 & 28.6 \\
\hline Ice hockey & 5 & 2 & 40.0 & 3 & 60.0 & 4 & 80.0 & 1 & 20.0 & 5 & 100.0 & - & - \\
\hline Floor-ball & 5 & 5 & 100.0 & - & - & 5 & 100.0 & - & 0 & 5 & 100.0 & - & - \\
\hline Swimming & 4 & 4 & 100.0 & - & - & 4 & 100.0 & - & 0 & 2 & 50.0 & 2 & 50.0 \\
\hline Rowing & 2 & 2 & 100.0 & - & - & 2 & 100.0 & - & 0 & 2 & 100.0 & - & - \\
\hline Skiing & 2 & 2 & 100.0 & - & - & 2 & 100.0 & - & 0 & 2 & 100.0 & - & - \\
\hline Tennis & 2 & 2 & 100.0 & - & - & 2 & 100.0 & - & 0 & 2 & 100.0 & - & - \\
\hline Handball & 2 & 2 & 100.0 & - & - & 2 & 100.0 & - & 0 & 2 & 100.0 & - & - \\
\hline Orienteering & 2 & 2 & 100.0 & - & - & 2 & 100.0 & - & 0 & 2 & 100.0 & - & - \\
\hline Cycling & 1 & 1 & 100.0 & - & & 1 & 100.0 & - & & 1 & 100.0 & - & \\
\hline Riding & 1 & 1 & 100.0 & - & & 1 & 100.0 & - & & - & & 1 & 100.0 \\
\hline Shooting & 1 & 1 & 100.0 & - & & 1 & 100.0 & - & & 1 & 100.0 & - & \\
\hline Climbing & 1 & 1 & 100.0 & - & & 1 & 100.0 & - & & - & & 1 & 100.0 \\
\hline Parachuting & 1 & 1 & 100.0 & - & & 1 & 100.0 & - & & 1 & 100.0 & - & \\
\hline Chess & 1 & 1 & 100.0 & - & & 1 & 100.0 & - & & 1 & 100.0 & - & \\
\hline Lacrosse & 1 & 1 & 100.0 & - & & 1 & 100.0 & - & & 1 & 100.0 & - & \\
\hline Motorsport & 1 & 1 & 100.0 & - & & 1 & 100.0 & - & & 1 & 100.0 & - & \\
\hline Total: & 96 & 90 & 93.8 & 6 & 6.3 & 84 & 87.5 & 12 & 12.5 & 82 & 85.4 & 14 & 14.6 \\
\hline
\end{tabular}

respondents gave an affirmative answer, but $15 \%$ did not agree to that. Basketball, hockey, floor-ball players, rowers, skiers, tennis, handball players and orienteering athletes were fully confident about the significance of movement games in forming social skills. A negative answer was received from swimmers (50\%), volleyball players (29\%), athletes $(20 \%)$, wrestlers $(13 \%)$ and gymnasts $(10 \%)$.

\section{DISCUSSION}

Based on the questionnaire survey we ascertained the knowledge of coaches about movement games and their practical experience in the use of movement games in the training process in different sports. We established how games were applied in the training process in Latvia, and compared results with those obtained in the questionnaire survey in 1994. In general, the questionnaire survey showed that coaches (84\%) were willing to apply movement games. However, some of them also were sceptic about the use of movement games in sport activities. While 94\% admitted that games facilitated physical abilities, some of them (87.5\%) claimed that games aided in the development of sport techniques, and only $85 \%$ of respondents were confident that games contributed to building up social skills. These statements are in contradiction to those mentioned in literature and those proved in the training practice. Physical Education including games and sports plays a tremendous role in the development of youth. It enables an individual to live in an everchanging world. Physical Education makes children psychologically, physically and physiologically active (Ajay, 2011). Games can help children develop physically, mentally and socially. Games are perfect means in the development of physical abilities, they facilitate sport techniques and they in the best way may contribute to developing social skills. Enough physical activity in the childhood, adolescence and youth is extremely important. 
Children master those motor skills that form the basis of all other physical activities lifelong in the childhood (Porozovs \& Klavina, 2014). By playing children improve their abilities to cooperate, to help each other, increase their individual responsibility and ability to work in a team. They learn to find solutions in different situations, to support each other, to encourage, to listen to, etc. (Vazne, 2006). Communication or exchange of information is considered to be the basic kind of interconnection. Interaction is the very first activity that a child masters in his/her development. Children's interaction and the development of competences occur as a result of social experience, especially in the interaction between a child and an adult. A child feels great satisfaction from common games where the process of information exchange takes place. Communicative competence includes a human's ability to solve communicative tasks with the help of language, voice as well as body language within the interconnection in different situations of the intercourse. It is possible to judge the level of a child's communicative competence considering the child's skill to communicate, i.e. to have common talks as well as the skill to listen, to collaborate with playmates in real life and imaginary situations. Within the interaction a child learns to imitate various real life situations through the game, to perform a role play, learns to apprehend as well as coordinate his/her actions with the playmates (Stangaine, 2010). Some respondents have mentioned that in professional sports games perfectly help to relieve psychological stress that accrues during the long and exhausting sport season that is a very important aspect. The fact that affirming responses to the second question "Do you include movement games in your training classes?" (79\%) prevail over those given to the first question (66\%) shows a positive dynamics. Responses to the third question are even more favourable $-84 \%$ of respondents consider games to be essential part of the training process. We are sure that the students of LASE should master the games and their methodology which in turn should facilitate their implementation in the training process in the way which is best suited for particular kind of sports. There are some kinds of sports where the games are not used at all. Probably the sports become more and more professional and less space remains for games. It should be also taken into account that the questioned respondents are still students who have not yet obtained the higher education degree in the sport pedagogy; they have only both positive and negative experience including experience in applying games in training process, which is gained from their own coaches. In our opinion, the movement games should be more implemented in some sports such as track-and-field, wrestling, football, gymnastics, floor-ball and swimming since the element of a game in these sports is very important. Probably the sports become more and more professional and less space remains for games.

Physical education professionals seek out avenues via which skills and interests developed within school can be pursued further, certainly in the case of those children who are keen and/ or show notable talent in sport. We can readily recognise that learning and involvement in physical activity and sport happens in many places and various times. Arguably there is a need for greater recognition that learning related to health and physical education needs to be ongoing for all young people, responsive to their ever changing life circumstances, needs and interests, and is by no means the sole concern or domain of those currently identified as physical education teachers (Penney \& Jess, 2004). Physical literacy serves as an important foundation for many sport and education policies. It is clear, therefore, that physically literate individuals not only move efficiently, but they also move creatively, competently, ethically, enthusiastically, and in socially responsible ways. Hence, individuals who are physically literate have the knowledge, skills, and attitudes to lead healthy lifestyles for themselves, and also assist others in acquiring these skills as well (Mandigo, Francis, Lodewyk, \& Lopez, 2009).

\section{CONCLUSIONS}

In 2012 movement games in sport classes were applied by coaches for $18 \%$ more than in 1994 $(a<.05)$. The results indicate positive tendency in practical application of movement games. In addition, in the questionnaire survey of 1994 $(80 \%)$ as well as in the questionnaire survey of $2012(84 \%)$ we noticed one more positive tendency that the coaches considered movement games to be essential and wanted to apply them more in future than at the time of the questionnaire survey (61 and 79\%). We hope that when the coaches get pedagogical education at LASE, study game organization and management methodologies, as 
well as understand the tremendous role of games in the educational process, they will use them more in various kinds of sports.

Respondents' views on the use of games confirm the beneficial effects of close and medium correlation between the results of questionnaire in various kinds of sports $(a<.05)$, what confirms the stated hypothesis. When coaches know and use movement games corresponding to the specific sports kind to increase athlete's interest and pleasure about sport and sport pedagogue's knowledge about the scientifically based movement games, they promote the acquisition of skills for specific kinds of sport at a higher level (Dravniece, 1999). Overall, students' attitude to movement games was positive. The feedback and comments of the students were encouraging.

To compare the results it is possible to make a questionnaire for different age group coaches with higher education.

\section{REFERENCES}

Ajay, K. (2011). Importance of physical education, games \& sports activities. VSRD Technical \& NonTechnical Journal, 2(11), 570-573.

Dauer, V. P., \& Pangrazi, R. P. (1989). Games. Dynamic Physical Education for elementary School Children. New York: Macmillan Publishing Company.

Dravniece, I. (1999). Kustíbu rotaļas sporta veidu apguvē: Doctoral dissertation. Riga: LASE.

Dravniece, I. (2013). Rotaļas LSPA studiju procesā kustību rotaļas vai kustību spēles? LASE Scientific and methodological papers 2013. Annual issue in Sport Science (13). Riga: LASE. Retrieved form http://www. lspa.eu/files/research/2013/2013_Dravniece_2_13.pdf

Dzintere, D., \& Stangaine, I. (2007). Rotaļa - bērna dż̄ves prasmju sekmētāja. Riga: Raka.

Haag, H., \& Haag, G. (2003). Game in Dictionary Sport - Physical Education - Sport Science (768). Kiel: Institut für sport un Sportwissenschaften.

Jansone, R., \& Fernāte, A. (2009). Kustību apguves un fizisko spēju attīstīšanās sporta stundās Rīga: ISEC. Retrieved from http://isec.gov.lv/pedagogiem/metmat/ kust_apguves.pdf

Laizāne, S. (1981). Kustību rotaḷas [Movement games] (120). Rīga: Zvaigzne.
Mandigo, J., Francis, N., Lodewyk, K., \& Lopez, R. (2009). Position paper physical literacy for educators. PHE Canada: Brock University. Retrieved from https:// www.phecanada.ca/sites/default/files/pl_position_paper.pdf

Penney, D., \& Jess, M. (2004). Physical education and physically active lives: A lifelong approach to curriculum development. Sport, Education and Society, 9, 22692287. Retrieved from http://www.castonline.ilstu.edu/ henninger/Pdf/KNR\%20419/SESPennycurriculardev. pdf

Porozovs, J., \& Kḷaviņa, A. (2014). Role of natural sciences in sports pedagogy. In Natural Sciences and pedagogy: Monograph (pp. 195-224). Riga: RTTEMA, University of Latvia.

Santrock, J. W. (2001). Child development. University of Texas at Dallas. McGraw-Hill Higher Education.

Stangaine, I. (2010). Pieaugušā un bērna sociālā mijiedarbība rotaḷā pirmsskolēna komunikatīvās kompetences sekmētāja. In Theory for practice in the education of contemporary society, 5th International Scientific conference (pp. 312-317). Riga: LSPA.

Vazne, Ž. (2006). Teorētiskās nostādnes sporta pedagoga pedagogiskajai praksei. Riga: LSPA. 